\title{
Problems in Foreign Language Education in the Turkish Education System: Pre-Service Teachers' Accounts
}

\author{
Seyit Ahmet Çapan a * (1) \\ ${ }^{a}$ Harran University, Faculty of Education, ELT Department, Şanlıurfa 63190, Turkey
}

Received 19 November 2020 | Received in revised form 12 March 2021 | Accepted 4 April 2021

\begin{abstract}
APA Citation:
Çapan, S. A. (2021). Problems in foreign language education in the Turkish education system: Pre-service teachers' accounts. Eurasian Journal of Applied Linguistics, 7(1), 397-419.
\end{abstract}

Doi: $10.32601 /$ ejal.911469

\begin{abstract}
Foreign language education is a highly controversial issue in the Turkish educational system. Despite innovative educational reforms done in the last three decades, achievement in foreign language education is far from yielding the expected results. It is of grave importance to seek for reasons underlying the underachievement in foreign language education in Turkey. Henceforth, the present study aimed at investigating pre-service English language teachers' perceptions about possible problems factoring into the underachievement in foreign language education. Adopting a qualitative methodology, the present study also intended to formulate insider suggestions to possibly fix the perceived problems. The present study employed content analysis to analyze the data obtained through group interviews and a structured form. Results pointed to the role of learners, teachers, curriculum and social factors as the prominent reasons triggering the well-established underachievement of foreign language education in the Turkish context. The study offered various implications for refinement of foreign language education in Turkey.

(C) 2021 EJAL \& the Authors. Published by Eurasian Journal of Applied Linguistics (EJAL). This is an open-access article distributed under the terms and conditions of the Creative Commons Attribution license (CC BY-NC-ND) (http://creativecommons.org/licenses/by-nc-nd/4.0/).
\end{abstract}

Keywords: Foreign language education; problems; underachievement; learners; teachers; curriculum; social factors

\section{Introduction}

\subsection{Background}

Turkey, just like almost all other countries, has made a lot of investments and efforts to teaching English as a foreign language (FL) since the early 1950s (Alagözlü, 2017; Kırkgöz, 2008). The reforms in FL teaching along with the general educational reforms made in the past 30 years are evident proofs of the importance Turkey has attached to learning and teaching English. With this respect, the 1997 educational

\footnotetext{
* Corresponding author. Tel.: +0-414-318-3466

E-mail address: sacapan@harran.edu.tr

http://dx.doi.org/10.32601/ejal.911469
} 
reform titled 8-year compulsory educational reform was a pioneering step as it started learning/teaching English from the 4th grade of primary education in public schools (Kırkgöz, 2008; Yaman, 2018). In addition to increasing the number of English lessons in the schedule, the 2006 reform emphasized a more communicative and learnercentered approach to FL education (Kırkgöz, 2008). In line with the principles of the Common European Framework of Reference for Languages, the 2012 reform (more commonly known as ' $4+4+4$ reform') lowered the level of teaching English to the 2nd grade in primary education with an action-oriented approach, which was further refined in 2018 to include values education so as to achieve a more effective FL education in Turkey.

All these efforts nonetheless, the overall underachievement in FL education in Turkey still lingers to be a salient handicap of the general education system. According to the English Proficiency Index (EPI, 2020), Turkey was ranked 69th among all the countries worldwide and second lowest among the European countries, which caused it to be categorized among the 'low level' countries in 2020. The same index (EPI, 2020) stated that in parallel with the fading dreams of joining the EU, teaching English in Turkey seemed to place heavy emphasis on grammar and translation rather than practical communicative skills while Turkish was the dominant language in English classes. Likewise, the TEPAV report maintained that Turkish FL learners focused more on giving correct answers to teachers' questions about English than communicating and functioning freely in English (TEPAV, 2013).

In fact, it will be unrealistic to attribute the underachievement of FL education in Turkey to a single reason (Coşkun Demirpolat, 2015). Instead, the underachievement of FL education has to be probed through a multidimensional and holistic approach including all the factors partaking in the process. With this regard, comprehensive analyses and working solutions can only be formulated through considering all the macro and micro factors such as (pre- and in-service) teacher education process, learner needs and interests, physical infrastructure in schools, school administrations, course books and materials, assessment and evaluation, FL education policies, development and evaluation of curriculum, and teacher employment policies (Kızıldağ, 2009; Solak \& Bayar, 2015; TEPAV, 2013). Considering the fact that it is impossible to cover all these diverse factors in a single study, it is observed that previous literature investigated problems of FL education in Turkey either from students' perspectives (e.g., Arıbaş \& Tok, 2004; Can \& Işık Can, 2014) or teachers' perspectives (e.g., Haznedar, 2010; Kızlldağ, 2009). However, this study delved into pre-service ELT (i.e., English language teaching) teachers' views on perceived problems of FL education in Turkey and possible suggestions. Consequently, this study intended to bilaterally shed light on problems of FL education in Turkey because pre-service ELT teachers could on the one hand reflect on impacts of the problems from an insider perspective (via their fresh memories of learning English as a student) and on the other hand suggest practical solutions from a professional perspective (via their growing knowledge of learning to teach English as a prospective teacher). The main research questions in this study were: 
1. What are the problems of FL education in Turkey from the perspective of preservice ELT teachers?

2. What possible suggestions do pre-service ELT teachers make for solving the problems of FL education in Turkey?

\subsection{Review of Literature}

Learners' motivation and attitudes towards learning a target language surfaced as two critical problems affecting their ultimate success. Despite the well-established role of English in engaging in international communication and getting a well-paid job, several studies (Akcan, 2016; Paker, 2007; Toköz Göktepe, 2014) reported that Turkish learners of English at different educational levels had low motivation and negative attitudes toward learning English. Given the status of English as an FL in Turkey, limited opportunity to use English outside the classroom was a prominent factor underlying the learners' low motivation and negative attitudes. Toköz Göktepe (2014) highlighted that overemphasis on grammar and vocabulary in English classes misled the 9th grade students in her study to perceive English merely as a course to be passed, which in turn cultivated in the students' negative attitudes towards learning it. Likewise, the fact that high-stakes tests for admission to universities in Turkey did not test proficiency in English partly explained learners' low motivation to learn it (Can \& Işılk Can, 2014; Paker, 2007).

Training effective teachers has also been identified as a major obstacle to effective FL education in Turkey. Although FL teachers as the only source of exposure to English are critical agents modeling their students effective FL use (Çelik, Arıkan, \& Caner, 2013), dramatic discrepancies are still common phenomena between the methodological approaches prescribed in teacher education programs and teacher practices in FL classrooms (Gedikoğlu, 2005; Inci \& Yıldız, 2019; Karcı \& Akar-Vural, 2011). A closer investigation into the problem of FL teachers and their training revealed that such discrepancies were only tip of the iceberg as the roots of the problem seemed to be entrenched deeply in more macro level elements like a predominantly theory-oriented teacher training, lack of a consistent continued professional development policy, teacher employment and induction procedures, and an unsystematic mentoring system. Even worse, alternative steps taken by the government to handle the specialized FL teacher shortage, which emerged particularly after the introduction of English as a compulsory course in primary schools as part of the 1997 educational reform, resulted in further problems. To clarify, any graduates (irrespective of their major) of universities where English was the medium of instruction, the graduates of open English teacher education programs, primary school teachers, and teachers of German/French were employed as teachers of English though they had little or no training about teaching English. Hence, these controversial steps aggravated the questions about FL teachers' qualifications rather than helping to resolve the FL education problem in Turkey (Karc1, \& Akar-Vural, 2011; Yaman, 2018). 
In the same vein, instructional practices featured to be a salient problem factoring into the success of FL education in Turkey. Various studies pinpointed that traditional teaching practices prevailed FL teaching due to such reasons as crowded classrooms (Ünal \& İlhan, 2017) and exam-based teaching (Peker, 2012). FL teachers seemed to prioritize completing the textbook activities in order to meet the requirements of the curriculum with a teacher-centered approach (Kara, Demir Ayaz \& Dündar, 2017; Solak \& Bayar, 2015). Moreover, they largely ignored adapting their teaching to the learners' needs and interest, which yielded the false impression that English should be learned as a subject rather than a means of communication (Can \& Işık Can, 2014; Işık, 2008). Finally, previous studies (Özer \& Korkmaz, 2016; Salı, 2014; Yurtsever Bodur \& Arıkan, 2017) found that lack of practice combined with teachers' overuse of the mother tongue largely hindered learners' achievement in FL learning.

Another major problem in FL education in Turkey referred to the issue of instructional materials. Several studies (Gedikoğlu, 2005; Kara et al., 2017; Kızıldağ, 2009) noted quality and quantity problems in the instructional materials enforced in a top-down manner in public schools. First and foremost, instructional materials lacked sustainability i.e., they did not systematically offer a progress across grade levels (TEPAV, 2013). Moreover, the TEPAV (2013) report unveiled that instructional materials failed in differentiating diverse learner needs and interests, which might result in disengagement of learners from learning English. Apart from the content, organization and audio-visual deficiencies and grammar-based activities in the textbooks surfaced as another factor seriously limiting the opportunity to engage learners in interactive and communicative use of English (Paker, 2007; Yllmaz, 2008).

An additional problem that should be handled tentatively is assessment and evaluation in FL education. On the one hand, there were criticisms on the ground that high-stakes tests like the university entrance exam did not include a section to test knowledge of English, which caused learners to undermine the importance of English and pay more attention to other school subjects (Öztosun, 2011). Nevertheless, Özer and Korkmaz (2016) cautioned about the washback effect of including English in highstakes tests. They (2016) asserted that as a result of including an English section in the high school entrance exams, FL learning/teaching practices focused merely on preparing learners for the exam at the expense of minimizing games and oral communication activities whereas learners showed increased interest in English classes. On the other hand, tests used to measure learners' progress in English classes featured to consist of grammar, vocabulary and partly reading. Previous studies (Bekleyen, 2007; Öztosun, 2011; Yaman, 2018) unanimously evidenced that productive skills and listening were mostly ignored in those tests. Therefore, there were several calls for a holistic, integrative approach to evaluation and assessment in FL teaching (Arıbaş \& Tok, 2004; Can \& Işık Can, 2014; Öztürk \& Aydın, 2019).

\section{Method}




\subsection{Research Design}

This study was an exploratory case study (Patton, 1990; Yin, 1994) as it sought for unearthing problems in FL education and possible reasons underlying them as well as insider suggestions for solving the identified problems. The study adopted a qualitative methodology by employing qualitative research instruments on the grounds that a qualitative methodology could better depict factors restraining effective FL education in Turkish context and provide in-depth understanding of possible ways to solve them.

\subsection{Setting and Participants}

This study was conducted at a public university in the South Eastern part of Turkey. The researcher contacted the head of ELT department and obtained official approval for informing and inviting pre-service ELT teachers to participate in the study. Selected through convenience sampling (Cohen, Manion \& Morrison, 2007), a total of 60 pre-service ELT teachers (21 males and 39 females) volunteered to participate in the study. They were in the second year of university education after completing a one-year, compulsory intensive English preparatory course. The average age range of the participants was 20 .

Moreover, the researcher ensured to use pseudonyms in data analysis and reporting in order to maintain true confidentiality and anonymity. Once the participants were selected, the researcher asked them to create groups of 4 (i.e., 15 groups in total) to engage in the study procedures. Granting the participants the freedom of choice instead of forming the groups in a top-down manner would maximize participation because the participants could freely reflect their ideas without any social barriers such as stress/fear of speaking with unknown people.

\subsection{Instruments}

This study employed qualitative data collections tools. A group interview was conducted with each of the 15 groups, which lasted approximately 20 minutes and were video-recorded. The group interviews focusing on the problems in FL education in Turkey required the group members to disclose their opinions about the problems they observed in FL classes throughout their educational life including primary, elementary, high school and preparatory course training as well as discussing possible suggestions (if any) with their group members to solve those problems. As another qualitative instrument, a structured form designed by the researcher was given to each participant in order to individually explain the problems they encountered in their FL education and their perceived solutions (Appendix A). This form intended to give the participants extra space for documenting their problems because some participants might have felt discouraged to openly voice their opinions in a group discussion atmosphere. 


\subsubsection{Data Analysis}

The researcher employed qualitative data analysis methods. Content analysis was used to analyze the data obtained from the group interviews and structured form. Using the constant comparison method (Cohen et al., 2007), the researcher read the verbatim transcripts of the interview videos and the participants' responses to the structured form, which enabled initial coding (Saldana, 2009) of the data on the basis of preliminary coding units. Then, the researcher read the whole data again for focused coding (Charmaz, 2006), which yielded the identification of major categories. Tally charts were used to keep a track of the participants' responses so that recurrent themes could be found.

As the analysis was done by the researcher only, there was need for determining both inter-rater and intra-rater reliability. For inter-rater reliability, the researcher shared a small portion of the qualitative data (i.e., randomly selected transcripts of only one of the group interviews and one of the participants' responses to the structured form) with the head of ELT department since she had already been informed about the purposes and procedures of the study. After she finished the analysis, a comparison was made between her and the researcher's own analysis of the same portion of the data. Using Miles and Huberman's formula of "number of agreements/ total number of agreements + disagreements" (1994, p. 64), agreement between the raters was found to be eighty-two percent, which according to Saldana (2009) represented a sufficiently good reliability. With respect to intra-reliability, the researcher re-coded the same portion of the data after a two-weeks interval and compared it with the earlier coding. Using the same formula (Miles \& Huberman, 1994), the intra-rated reliability was found to be ninety-two percent.

\section{Results}

This study divided the results of the content analysis into four main themes; namely, problems related to a) learners, b) teachers, c) curriculum, and d) social factors. As can be seen in Figure 1, each theme included further categories. To be reader-friendly, problems and suggestions regarding each theme were presented together. 


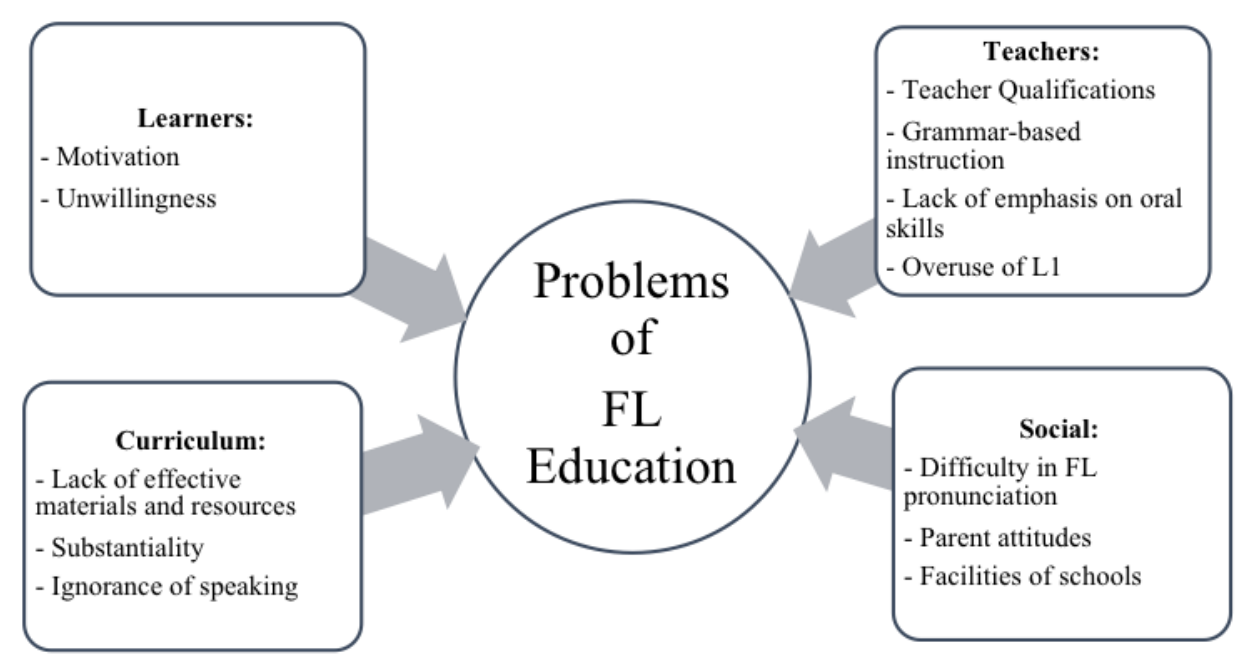

Figure 1. Problems of FL education in Turkey

\subsection{Problems and suggestions related to learners}

This study revealed that lack of motivation and unwillingness to learn English were the two main learner-related factors that hindered achievement in FL education. The participants in the study proposed that certain factors had negative influence on Turkish learners' motivation and willingness to learn English, which played a major role in the failure of FL education in Turkey (See Figure 2). The participants unanimously stated that limited opportunities for using English inside and outside the classroom undermined the need for learning it. The participants also emphasized that exam-oriented teaching discouraged FL learners from making additional efforts to learn English because over-emphasis on exams deprived them of the joy of learning a different language. Furthermore, the study found that error correction techniques utilized by teachers seemingly did not pay much heed to students' emotions and thusly, fostered unwillingness to participate in classroom activities in FL classes. Likewise, learners' affective reactions such as anxiety and fear of making mistakes decreased their motivation and willingness to learn English. Interestingly though, some of the participants in the study also marked little reference to cultural knowledge in FL classes as another problem deterring success in FL education. One of the participants highlighted the negative impact of lack of cultural knowledge of the target community on their motivation to learn English by asserting that "(i)f our teachers taught us more about English way of life, their culture and traditions, it could give us a stronger incentive for learning English than learning about grammatical rules" (Eulalia). 

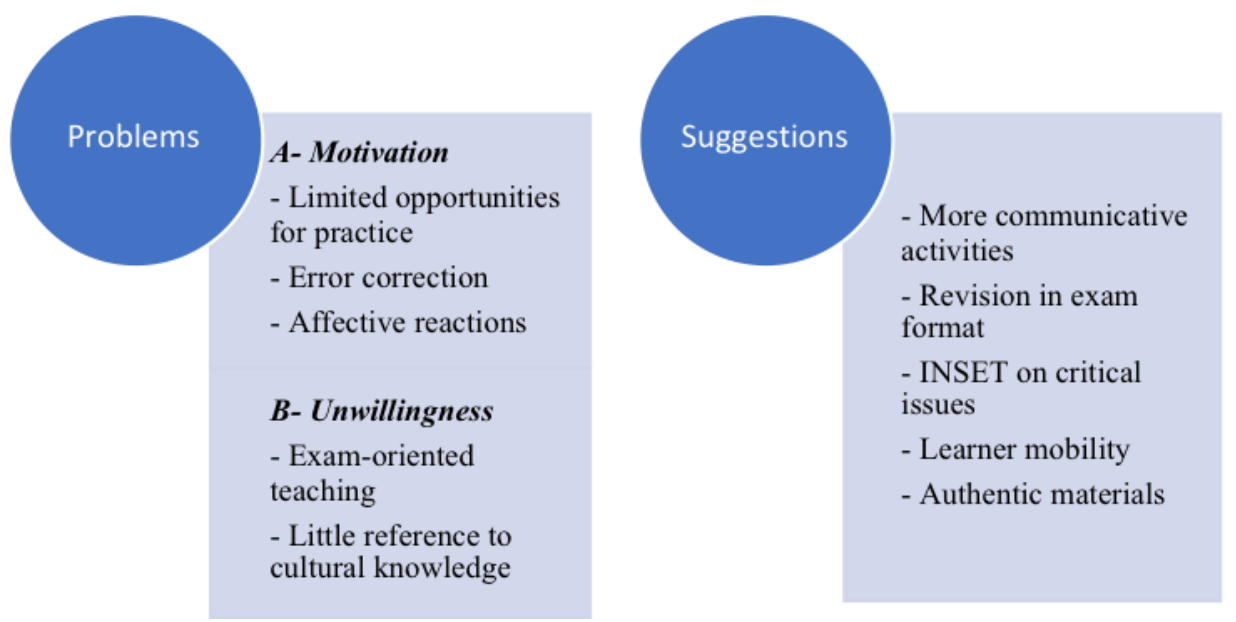

Figure 2. Problems and suggestions related to learners

As possible solutions to handle learner-related problems, this study yielded various suggestions. Firstly, the participants recommended that FL classes should place more emphasis on communicative activities to provide learners with extensive opportunities for FL practice as well as online applications offering interactive practice facilities. Secondly, the participants argued for a revision in the current exam format. To replace the over-reliance on exams, one of the participants explained that "the exam format should be changed to address all four skills rather than merely grammar and vocabulary" (Rebecca). Moreover, the study shed light on the role of inservice teacher training programs in informing teachers about some critical points like appropriate error correction and feedback techniques in FL classes. Similarly, the study indicated that the criticism about little reference to cultural knowledge of the target community could alternatively be handled in two ways. The study pinpointed that student mobility programs which enable mutual student exchange such as Erasmus+ and Commenius could prove conducive for increasing learners' knowledge about the FL culture and developing positive attitudes towards the target community. The other option to foster input about cultural knowledge, as one of the participants illustrated, is to "use authentic materials such as songs, poems, and movies/TV series in order to help to improve Turkish students' cultural knowledge in addition to increasing their motivation" (Sylvia).

\subsection{Problems and suggestions related to teachers}

This study pointed out four themes as teacher-related problems affecting achievement in FL education in Turkey, which comprised poor teacher qualifications, grammar-based instruction, lack of emphasis on oral skills, and overuse of L1 (See Figure 3). Despite a large number of comments on teachers, there were no criticisms about their content knowledge except for pronunciation. Instead, the participants reported problems largely related to teachers' instructional practices. Regarding teacher qualifications, the study unearthed that traditional methods and techniques were prevalent in FL classes such as asking-answering questions and rote-drills. Moreover, the participants asserted that teachers failed in addressing learners' needs 
and interests while they were teaching in the classroom. Similarly, the participants implied unsatisfactory integration of technological innovations in FL teachers' practices. Another issue about teacher qualifications referred to deficiencies in testing (i.e., assessment and evaluation), which one of the participants clarified by recounting that "our teacher merely asked questions about grammar and vocabulary in the exams. She did not care if our communicative skills are good or not" (Nuria). The participants' reflections unveiled that a possible explanation for the perceived problems related to teacher qualifications was a lack of specialized FL teachers, particularly in rural parts of the country, given such remarks as "our English teacher was actually a graduate of physical education department" (Emily) and "the viceprincipal was teaching us English in primary school" (Sally).

\begin{tabular}{|l|}
\hline Teacher qualifications \\
\hline - Traditional methods and \\
techniques \\
- Failure in tapping learner \\
needs and interests \\
- Unsatisfactory \\
integration of technology \\
- Deficiencies in testing \\
- Unspecialized teachers \\
\hline
\end{tabular}
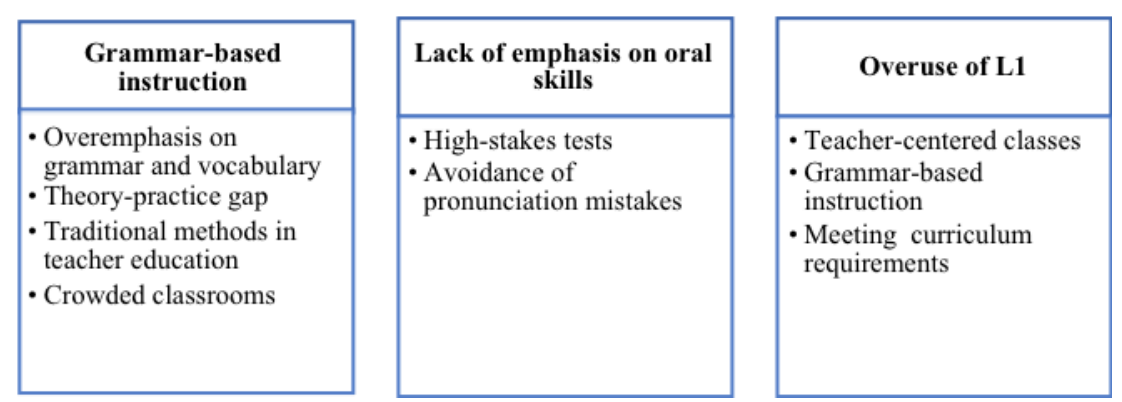

Figure 3. Problems related to FL teachers

As to the problems stemming from teachers' grammar-based instruction, the participants underlined that teachers' practices heavily emphasized teaching grammar and vocabulary. The participants' reflections illustrated that certain factors formed the roots of this problem. More precisely, the notorious gap between the theoretical knowledge in pre-service teacher education and practice in actual classrooms resulted in grammar-based instruction. According to some of the participants, traditional methods in pre-service teacher education also helped to explain teachers' over-emphasis on grammar. Furthermore, the participants posited that the number of students in the classroom was a restrictive factor because crowded classrooms "inhibited using practical activities" (Nuria).

Another major teacher-related problem referred to a lack of emphasis on oral skills. The participants claimed that teachers did not pay due attention to listening and speaking skills in FL classes, which promoted underachievement in learning English. Yet, the study found out that teachers' tendency to shape their teaching according to high-stakes tests in Turkey caused them to focus on grammar and vocabulary. Hence, the washback effect of this tendency led to the ignorance of oral skills in FL classes. One of the participants stressed this tendency as she maintained that "there were mostly grammar and vocabulary questions in TEOG (i.e., high-school admission test). So, our teacher did not teach practical and productive skills like speaking" (Marcus). In addition, the study attributed some role to teachers' avoidance of pronunciation mistakes in their lack of emphasis on oral skills. The participants' reflections indicated that FL teachers were not "confident about pronunciation; so, she (i.e., the teacher) did not do almost any speaking activity” (Barbara). 
The last teacher-related problem, overuse of L1 intriguingly hinted on insufficient use of English in FL classes. The study highlighted that FL teachers used the learners' mother tongue as the main medium of instruction. The participants also proposed that teachers' use of mother tongue in essentially teacher-centered FL classes triggered further drawbacks such as reducing learners' exposure to the target language, casting doubts about functional use of English as a medium of communication, and promoting learners' ineffective development of communicative skills in English. One of the participants expressed her concern about teachers' overuse of L1 by stating that "we have a problem of speaking second language in our country. Our previous teachers, our educators teach us English with Turkish. With this education style, we are not educated for speaking English" (Maria). The study revealed that grammar-based instruction partially explained overuse of L1 in FL classes because teachers frequently resorted to L1 in order to explain grammatical rules. Additionally, the need to meet curricular requirements urged teachers to use mostly L1 in the classrooms as one of the participants noted that "speaking Turkish is like a must for teachers of English in order to complete everything in the curriculum imposed by the government" (Sally).

With respect to suggestions about solving teacher-related problems, this study summarized the participants' reflections in three overarching categories (See Figure 4). The first set of suggestions indicated a clear need for refining pre-service and inservice teacher education programs by increasing (pre-service) teachers' awareness and use of changing trends in instructional methodologies for teaching English. Teacher education programs should also place particular emphasis on providing teachers with more opportunities for practice in real classrooms. With this regard, the participants specified features of an effective teacher education program by making such remarks as “...more practical training for pre-service teachers, especially giving pre-service teachers practice on how embrace communicative activities like games, group/pair work" (Chris) and "more practice for teacher candidates to use interactive methods and techniques such as games, group work and digital technologies for everchanging generation" (Barbara). Likewise, professional development programs should periodically be organized for in-service teachers on ways of teaching all four skills effectively rather than grammar and vocabulary only.
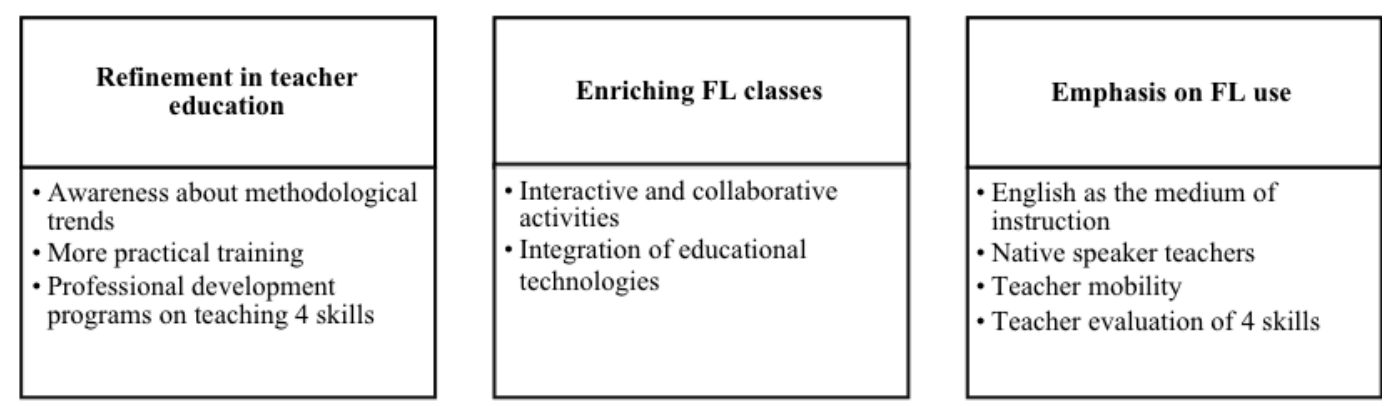

Figure 4. Suggestions to solve teacher-related problems

Secondly, the study evidenced the necessity of enriching FL classes by interactive and collaborative activities for an optimal FL learning/teaching. The participants 
postulated that to overcome ignorance of interactive skills (i.e., listening and speaking), "communicative activities like drama, music and games could be used to maximize input and output, especially in the initial phases of FL education" (John). Moreover, the study underlined that integration of educational technologies into FL classes could offer an individualized and student-centered classroom atmosphere, which would thusly make learning English more attractive for learners. One of the participants documented that "using online games can help us improve different skills such as writing, speaking and listening in a stress-free environment" (Jessica).

The last set of suggestions about teacher-related problems pertained particularly to fostering the use of English in the classroom. The participants reported a clear favor for the use of English as the medium of instruction except for some exceptions like explaining a difficult learning point to ensure learners' comprehension. The participants similarly suggested that they "should have native speaker teachers because they know not only four skills but also culture of English" (Jane). Surprisingly, the study unearthed that teacher mobility programs could prove efficient in improving FL teachers' content and cultural knowledge. One of the participants explicated possible contributions of mobility programs to teachers' use of FL in the classroom by documenting that "teacher mobility can increase teachers' use of English by providing opportunities to practice speaking and listening and improve their cultural knowledge" (Eloise). Another interesting suggestion required periodical evaluation of FL teachers on four skills. With the rationale of encouraging teachers' FL use, the participants illustrated that "testing teachers on four skills every other year will make them speak English whenever possible" (John).

\subsection{Problems and suggestions related to Curriculum}

This study subsumed problems related to curriculum and course books under the roof term curricular problems. Overriding themes in this category included lack of effective materials and resources, substantiality, and ignorance of speaking (Figure $5)$. The study unearthed that although there were no problems in terms of access to the course books provided by the MoNE free of charge, there were sound questions about their effectiveness. The participants' reflections implied dramatic inconsistencies between the content of course books and the emphasis on the communicative approach in the curriculum enforced by the MoNE. The participants postulated that along with disregarding the natural order of acquisition of four skills in native speakers (i.e., listening, speaking, reading and writing), exercises in the course books placed such a grave importance on grammar and vocabulary that there was little space for developing main language skills. Likewise, the number of productive activities in the course books was considered far from fostering the use of English for functional purposes. In addition, the study underlined that course books did not include authentic materials, which would "promote a sense of real language use" (Amy). 


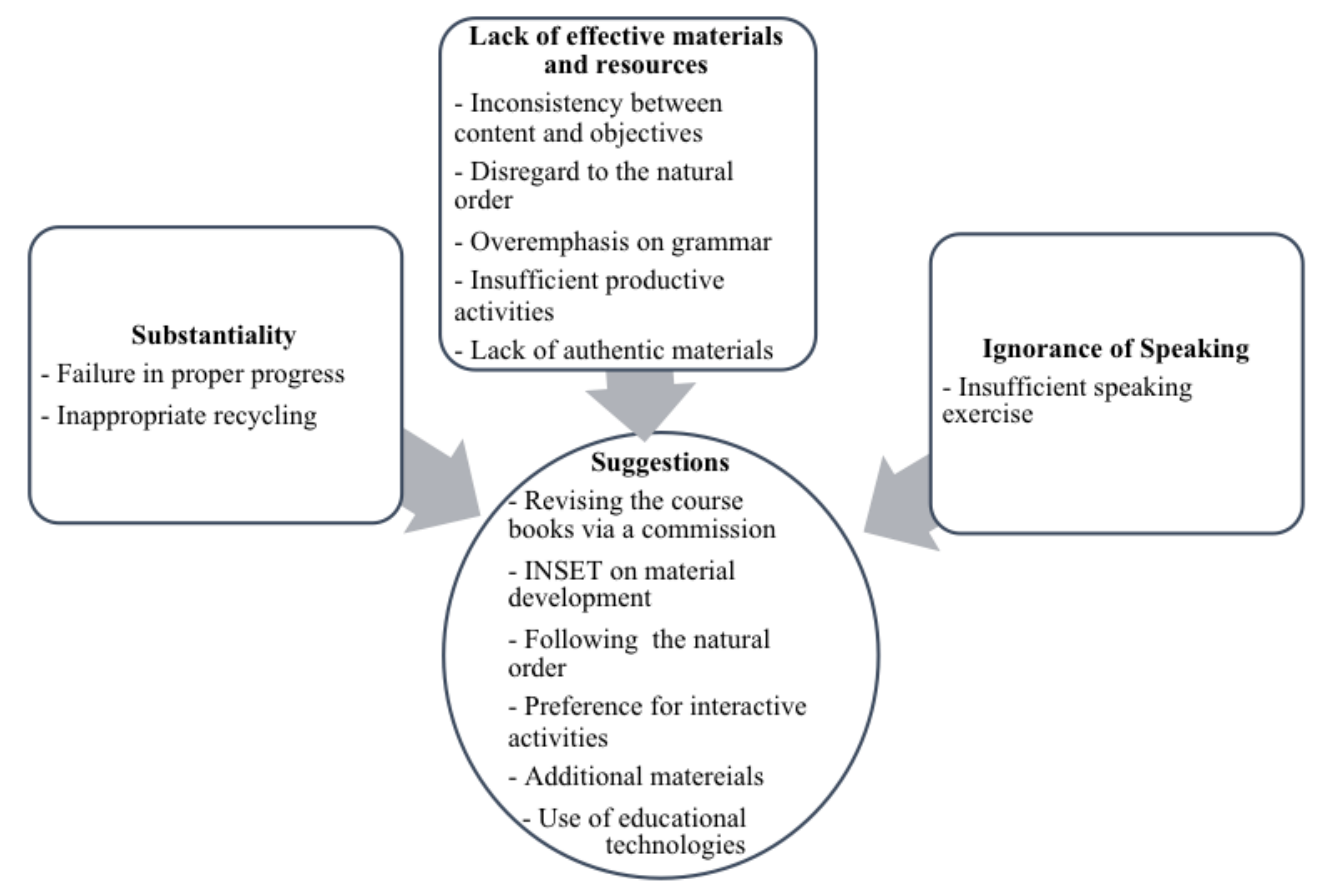

Figure 5. Problems and suggestions related to curriculum

With respect to substantiality, the study revealed that the FL curricula failed in progressing properly to support learners' FL development across grade levels. Also, the participants referred to inappropriate recycling in the curricula as one of the participants maintained that "we are always repeating the same content every year. I mean we start with simple present and end with present perfect. We are parroting the same order" (Nuria). The other problem was related to the ignorance of speaking skills. The participants unanimously argued that the main deficiency in the course books was the insufficient number of speaking exercises though "speaking must be the ultimate goal for all this much effort for learning English" (Alice).

As for suggestions to solve curricular problems, the study intriguingly demonstrated that all calls for refinement focused on course books rather than the FL curricula as a whole. More precisely, the study indicated a dire need to revise the content of course books. A close investigation of the participants' reflections projected a systematic process for achieving this revision, which extended from the selection and training of contributors to the type of exercises to be included in the revised version of the course books. The participants posited that a commission of course book designers should be formed with both native speakers and local teachers. The reason for involving native speakers was to benefit from the large-scale experience of international publishing houses whereas local teachers would serve noticeable functions to "adapt the course books to the socio-cultural context of the Turkish education system" (Barbara). Nevertheless, the study conveyed that the local teachers contributing to the course book development process should receive "in-service training for effective material development to help teacher structure and re-structure teaching materials in accordance with modern teaching methods" (Eric). Furthermore, the study pointed out that the revision attempts should ensure smooth progression of 
the content from simple to advanced topics as well as replicating the natural order of acquisition. Regarding the exercises, the participants displayed strong preference for interactive activities "like games, songs and word cards with visuals in order for enjoyable and long-lasting learning" (John). The participants also argued for offering additional materials including audio-visual aids in addition to course books and boards such as flash cards, videos and computers" (Carl). To circumvent the perceived insufficiency of the speaking activities, however, the study ascribed certain role for educational technologies. One of the participants clarified this role by stating a need for "using online communication synchronous (like Skype, Whatsapp) and asynchronous (like email, Facebook) applications to communicate with English speakers in cases of limited speaking exercises" (Olivia).

\subsection{Problems and suggestions related to social factors}

The last major theme in this study, social factors comprised Turkish learners' difficulty in learning FL pronunciation, negative parent attitudes and facilities of Turkish schools (Figure 6). Even though the issue of pronunciation might sound as an educational factor, the reason for aligning it with social problems was the fact that the participants' arguments basically focused on the difference between the sound systems of Turkish and English. With this respect, the participants partly attributed their difficulties in learning FL pronunciation to the fact that some sound in English (e.g.: the diphthong -th) did not exist in Turkish. Whereas Turkish was an alphabetic language, the mismatch between sounds and letters in English pronunciation system, in which 26 letters correspond to a total of 44 sounds, surfaced as a strong challenge for Turkish learners of English. The vast variety across different accents of English further aggravated the problem as one of the participants recounted that "I really feel confused about some words. Pronunciation in British English is highly different from American English" (Isabel). Moreover, the participants noted that lack of exposure to English in their immediate social environment as another obstacle to their achievement in learning pronunciation and overall English. 


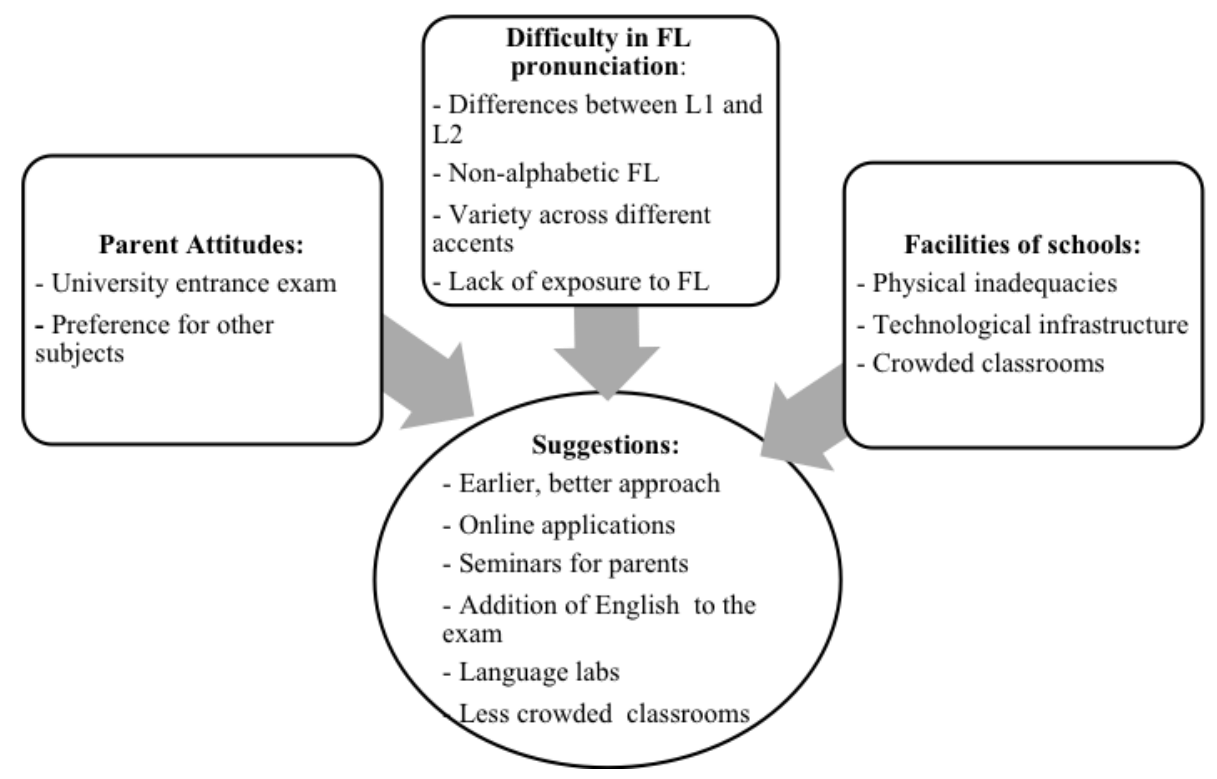

Figure 6. Problems and suggestions related to social factors

As for parent attitudes, the study found that contrary to the widespread recognition of English as a lingua franca, parents held negative attitudes towards the emphasis on English in overall educational curricula. The participants linked such negative attitudes of their parents with the university entrance exam used in Turkey. Reflecting the views of the majority, one of the participants explained that "the education system in Turkey fails in conveying our parents the necessity of English by not including it in the YGS (i.e., university entrance exam)" (Amy). Closely related to this explanation, the participants claimed that their parents held a strong preference for other subjects over English since they "perceived math and science to be more prestigious" (Sophia). Regarding the facilities of Turkish schools as a factor leading to underachievement of FL education in Turkey, pre-service teachers of English in this study mainly referred to the physical inadequacies and deficiencies in technological infrastructure such as "lack of appropriate materials and tools including projection and sound system" (Carmen), "lack of internet in most of the schools" (Eliza), and overcrowded classrooms. Clarifying the negative impact of crowded classrooms on effective FL education, one of the participants specified that "teachers cannot pay enough attention to all students... It is almost impossible to do peer or group work activities as long as there are approximately 30-40 students in the classroom" (Lily).

The study evidenced that social problems were observed to have a restrictive nature given the limited number suggestions the participant made to solve this kind of problems. Nonetheless, the study revealed that an 'earlier, better' approach to FL education featured as a favorable solution for mastering pronunciation difficulties. The participants also suggested using online applications to overcome pronunciation difficulties by such remarks as "increasing use of monolingual dictionaries with transcription and listening options" (Susan) and "good way for a learner to audiorecord himself via his mobile phone and correct his mistakes while pronouncing a 
word" (Nancy). To handle negative attitudes of parents toward English, the study pointed out that "seminars can be organized for parents about the role of English by language teachers/experts and school counseling service staff" (8d). Adding a section to test English proficiency to the university entrance exam also seemed to hold a strong potential for overcoming parents' negative attitudes. With reference to physical inadequacies and technological infrastructure, the participants unequivocally advised to "establish language labs with special facilities to learn English" (Rafael). The only suggestion this study could make about the issue of crowded classrooms was to have "less crowded classes enabling more enjoyable activities like peer and group work" (Jane).

\section{Discussion}

Recent and frequent reforms, nonetheless, achievement in FL education is far from being satisfactory in Turkey. In an attempt to shed light on factors underlying the underachievement of FL education, this study reported four main categories of problems i.e., problems related to learners, teachers, instructional materials and social factors. Regarding learner-related factors, this study confirmed Yurtsever Bodur \& Arıkan's (2017) finding that the participants put little blame on learners for the failure of FL education in Turkey. As the learner-related factors, this study identified FL learners in Turkey with low motivation and sound unwillingness to learn English. Further analysis of the data conveyed that low motivation and unwillingness on the part of learners stemmed from various characteristics of FL education in Turkey including lack of practice in English, emphasis on exams, inappropriate error correction techniques, affective factors, and lack of cultural knowledge. Given the positive correlation between high motivation and willingness and success in FL learning (İnal, Evin, \& Saracaloğlu, 2005), this study suggested that opportunities for practice along with such extracurricular activities as listening to music and reading books in English, using online applications to help study English and watching TV in English could foster motivation and willingness to learn English. Echoing the findings of the TEPAV report (2013), this study also postulated that using authentic materials could better address learners' interests and thereby, increase their motivation to learn English. As a creative alternative, this study underlined the role of mobility programs in contributing to learners' motivation and willingness. Along with supplementing cultural knowledge, organizing international mobility programs, which enable learners to visit and live in the target community for a certain period of time, may facilitate FL learning by giving extensive opportunities for real communication with native speakers (Can \& Işılk Can, 2014; Yaman, 2018).

Regarding teachers, this study found four prominent factors including poor teacher qualifications, grammar-based instruction, lack of emphasis on oral skills, and overuse of L1. With particular reference to teacher qualifications, the participants' emphasis merely on instructional practices rather than content knowledge concurred with previous findings (TEPAV, 2013, 2015) that teachers of English in Turkey had adequate proficiency to teach effectively. Nevertheless, this study unearthed several 
criticisms about FL teachers' instructional practices such as traditional methods and techniques in teaching, insufficient integration of educational technologies into classrooms, and failure in tapping learner needs and interests. As a possible explanation for such criticisms, numerous studies (Işık, 2008; İnceçay, 2012; Karcı \& Akar-Vural, 2011; Seferoğlu, 2004) highlighted that the lack of specialized teachers in Turkey was a major obstacle leading to the failure in FL education. Similarly, this study implied that alternative training programs (e.g.: open teacher education programs) to meet the high demand on FL teachers were of little help to solve the problem of FL education in Turkey. Instead, the MoNE should insist on employing graduates of regular ELT programs who can keep pace with such changing trends in FL education as the implementation of student-centered, communicative practices (e.g.: peer/group work) and alternative assessment techniques on all four skills (e.g. self/peer assessment, portfolios, individual/group projects, reflective journals etc.) along with the educational technologies (e.g.: online games, digital storytelling). In accordance with Mirici's (2001) call for reconsideration of the qualifications of FL teachers, this study proposed that in-service teacher training programs should periodically be organized to equip teachers with the knowledge of the latest methodological developments.

Moreover, this study reported overemphasis on grammar and vocabulary in contrast to the vast ignorance of oral skills in teacher practices. Connoting with previous literature (Öztürk \& Aydın 2019; Seferoğlu, 2006), this study pinpointed that apart from crowded classrooms, the theory-practice gap between pre-service teacher education and actual classrooms partially explained the FL teachers' overemphasis on grammar. In the same vein, the perceived lack of oral skills in teacher practices substantiated Özer and Korkmaz's (2016) argument about the washback effect of high-stakes tests on FL education. Considering success in high-stakes tests the criterion for FL achievement, teachers ignored speaking and listening activities for the sake of preparing learners for the exams, which may have undermined the actual joy of learning English for communication and thus, triggered underachievement in FL education. Lastly, this study unveiled that the predominance of L1 in teacher practices was closely related to grammar-focused, teacher-centered teaching as well as FL teachers' need to meet requirements of the curriculum. Despite the preconceived advantages of a principled use of L1 in certain cases such as giving instructions (Harmer, 2007; Kırkgöz, 2014; Sall, 2014), this study advocated that FL teachers should pay due attention to using English as much as possible. To increase teachers' FL use, this study suggested that international teacher mobility programs would be a viable option in addition to periodical evaluation of teachers on all four skills. According with various advantages coined by several researchers (Akcan, 2016; Alagözlü, 2017; Haznedar, 2010), this study concluded that such mobility programs would provide extensive contact with native speakers and contribute to FL teachers' overall proficiency and cultural knowledge.

Furthermore, this study pointed out that instructional materials posed a certain set of problems hindering effective learning and teaching of English in Turkey. Within 
this category, lack of effective materials and resources featured as a main deficiency. Although the MoNE curriculum (MEB, 2018a, 2018b) openly emphasized conformity with the communicative approach, this study revealed sound questions about the quality of course books. In line with previous studies (Paker, 2007; Ünal \& İhan, 2017; Yllmaz, 2008), insufficient number of productive activities contrary to overemphasis on grammar, lack of authentic materials, and ignorance of natural order of language acquisition in the course books were the main sources of criticisms about the instructional materials. As argued in the TEPAV report (2013), the issue of substantiality in the course books interfered with the effectiveness of FL education because the lack of progression between grades would lead to a failure in realistically supporting learners' engagement and learning. This study also corroborated Yllmaz's (2008) finding that course books were not designed appropriately for creating an FL learning environment which would enable effective development of oral communication skills, particularly speaking.

To overcome problems related to instructional materials, this study necessarily made a call for revising the content of course books through contribution of an international commission formed by native and local teachers and material development specialists. On the one hand, inclusion of native speaker teachers/material development specialists in this commission was considered a must for promoting authenticity (Coşkun Demirpolat, 2015). On the other hand, giving local teachers/material development specialists a voice in this commission could benefit FL education in various ways such as ensuring compatibility with the characteristics of the Turkish education system (Copland \& Garton, 2014). Moreover, this study underlined that the revised course books should be designed in a way to ensure flexibility in order to meet diverse learner needs and interests (TEPAV, 2013). Paying heed to Coşkun Demirpolat's (2015) argument for a smooth progression in terms of difficulty, this study also required that the content of course books proceed from simple to advanced topics and appropriately progress by including new learning points across grades. More importantly, this study evinced that enriching course books via more interactive activities with audiovisual facilities (e.g.: online games, songs) could prove highly practical to improve the quality of instructional materials (Aydınlı \& Ortaçtepe, 2018; Öztosun, 2011;).

Nonetheless, this study indicated that social problems undermining effectiveness of FL education were heavily related to the status of English in Turkey and facilities of Turkish schools. Given the problems FL learners experienced in learning pronunciation in English, this study clearly favored for an 'earlier, better' approach to learning/teaching English. In line with the cognitive and affective advantages associated with an earlier start (Halliwell, 1993; Krashen, 1982), this study posited that teaching English as early as possible could be beneficial for facilitating learners' mastery of pronunciation skill. With this regard, this study supported the recent curriculum reforms in Turkey as the last reform lowered the teaching of English to the 2 nd grade in primary education (MEB, 2018a). Similarly, this study supplemented previous calls (Aydınlı \& Ortaçtepe, 2018; Solak \& Bayar, 2015; Uysal, 2012) for 
integration of educational technologies into FL classrooms on the grounds that using technology (e.g.: mobile phones, online dictionaries) increases learners' exposure to English and thereby, helps to overcome the perceived difficulties in learning appropriate pronunciation of English words.

As another prominent finding regarding social-related problems, this study intriguingly highlighted that despite the aforementioned washback effect (Özer \& Korkmaz, 2016), adding an English proficiency section to the university entrance exam surfaced to be the only option for overcoming parents' negative attitudes toward English. Nevertheless, an equally salient and risk-free option was to organize seminars to help parents better understand the necessity of learning English compared to other subjects. Finally, this study confirmed findings of previous studies (Coşkun Demirpolat, 2015; Kızıldağ, 2009; Uysal, 2012) about the well-established issue of facilities of Turkish schools including physical inadequacies, technological infrastructure and overcrowded classrooms. To handle deficiencies stemming from physical inadequacies, this study accorded with Coşkun Demirpolat's (2015) suggestion that free-access language labs equipped with computers, which would offer materials suitable for different proficiency levels, should be established in Turkish schools. The other suggestion this study noted to solve the issue of crowded classrooms simply required to have fewer students in the class as a way to enable more enjoyable FL education.

\section{Conclusions}

In conclusion, this study shed light on problems underlying the highly disputed issue of underachievement in FL education in Turkey. As a distinctive feature of the findings, the study delved into perspectives of pre-service ELT teachers in order to capture a more thorough picture of FL education in Turkey because the participants would reflect not only learners' but also prospective teachers' views about the perceived problems and possible suggestions for solving those problems. Of the four categories of perceived problems including a) learners, b) teachers, c) instructional materials, and d) social factors, the study highlighted that problems related to teachers surfaced to be of the highest frequency, which thusly revealed certain implications for refinement of teacher education programs. Given the findings about FL teacher qualifications, the study implied that along with effective integration of educational technologies, teachers of English needed more practical training and guidance about how to fine-tune their practices in the light of the changing trends in language teaching methodologies. Criticisms about grammar-based instructions also underlined that teacher education programs should provide pre-service teachers with ample opportunities for gaining hands-on experiences about using communicative activities in FL classrooms. With particular reference to the widespread ignorance of oral skills, the study premised that immediate actions should be taken to help FL teachers effectively model the functional use of English in the classroom. For this purpose, the study suggested that mobility programs which would enable teachers to realistically use English for communicating in the target community might serve 
considerable function as well as fostering their cultural knowledge. Similarly, collaboration with native speaker teachers who have formal degrees in teaching English as a foreign/second language can give Turkish FL teachers valuable insights about teaching all four language skills rather than merely emphasizing grammar and vocabulary.

With respect to learner-related problems, this study unearthed that innovative steps should be taken to promote learners' motivation and willingness to learn English. First and foremost, authentic materials should be employed in FL classrooms since these materials can reflect real language use better than simplified materials. Another prominent step might be to increase the number of student mobility programs. Spending some time in an English-speaking community could give learners sound inspiration for learning English apart from making considerable contributions to their cultural knowledge. Furthermore, revision of the exam formats through inclusion of alternative assessment techniques in order to address all four skills might also make an imprint on learners' motivation and willingness. More specifically, learners could feel more motivated to learn English upon realizing that they can successfully listen, speak, read and write in English in contrast to merely memorizing grammatical rules and lists of vocabulary.

Considering the perceived role of the problems related to instructional materials in the underachievement of FL education in Turkey, the study called for a systematic refinement of the materials. A salient implication about the course books was the need for redesigning their content through collaboration of native and local materials designers instead of the top-down selection by the MoNE. Similarly, the study hinted on restructuring the content of course books in order to ensure that the course books involved more communicative activities proceeding from simple to more advance topics. More importantly, the study postulated that substantiality between grade levels was a must for effective FL education because constant repetition of the same content along with ineffective recycling evidently disengaged the learners from the joy of learning a foreign language.

The problems related social factors, however, necessitated that educational technologies should be emphasized in order to counterbalance the disadvantages stemming from the formal status of English in Turkey. Online applications with interactive facilities could be a panacea for enhancing learners' mastery of English pronunciation system as well as providing opportunities for communication (synchronous and asynchronous) via English. Establishing less crowded language labs with special facilities featured to a viable option that might help to go a long way in this regard. Finally, the study suggested that parents' negative attitude towards English compared to other subjects should be overcome in order for an effective FL education through such ways as seminars and inclusion of English in the high-stakes tests.

Nevertheless, one should notice that the findings of the study were limited in certain ways. Firstly, while the fact that the participants were majoring in English 
language teaching was considered strength of the study, it might have also affected the results due to the evident favor of the participants for English. That's why further studies with participants from various major areas might yield more comprehensive results. Secondly, the fact that the participants were selected from only one university might have featured as another limitation because inclusion of participants from various universities might have yielded different results. Furthermore, analysis of the data might have limited the results because no qualitative analysis software was used. Future studies using software (e.g. NVIVO, MAXQDA) might yield different results. Yet, the results of the study should be interpreted in the light of its own context as the study did not actually intend generalizability to other contexts.

\section{The Research and Publication Ethics Statement}

The Ethics Committee/Board approval for this study was obtained from Harran University Education Faculty in 08/07/2020 by No 5/8/20-300. No ethical considerations were violated in this study.

\section{The Conflict of Interest Statement}

In line with the statement of Committee on Publication Ethics (COPE), I hereby declare that I had no conflicting interests regarding any parties of this study.

\section{References}

Akcan, S. (2016). Novice non-native English teachers' reflections on their teacher education programmes and their first years of teaching. PROFILE Issues in Teachers' Professional Development, 18(1), 55-70.

Alagözlü, N. (2017). Türkiye'de İngilizce öğretmeni yetiştirme sorunları. Türkbilig, 34, 241247.

Arıbaş, S., \& Tok, H. (2004). İlköğretim birinci kademesinde yabancı dil öğretiminde karşılaşılan sorunların değerlendirilmesi. XIII Ulusal Eğitim Bilimleri Kurultayı, Malatya.

Aydınlı, J. \& Ortaçtepe, D. (2018). Selected research in applied linguistics and English language teaching in Turkey: 2010-2016. Language Teaching, 51(2), 210-245.

Bekleyen, N. (2007). An investigation of English teachers candidates' problems related to listening skills. Electronic Journal of Social Sciences, 21(21), 91-105.

Can, E., \& Iş̧ı Can, C. (2014). Türkiye'de ikinci yabancı dil öğretiminde karşılaşılan sorunlar. Trakya Üniversitesi Eğitim Fakültesi Dergisi, 4(2), 43-63.

Charmaz, K. (2006). Constructing grounded theory: A practical guide through qualitative analysis. London: Sage Publications.

Cohen, L., Manion, L., \& Morrison K. (2007). Research methods in education (6th ed.) New York, NY: Routledge.

Copland, F., \& Garton, S. (2014). Key themes and future directions in teaching English to young learners: Introduction to the special issue. ELT Journal, 68(3), 223-230.

Coşkun Demirpolat, B. (2015). Türkiye'nin yabancı dil öğretimiyle imtihanı: Sorunlar ve çözüm önerileri. Analiz, 131, 1-24.

Çelik, S., Arıkan, A., \& Caner, M. (2013). In the eyes of Turkish EFL learners: What makes an effective foreign language teacher. Porta Linguarum, 20, 287-297. 
EPI (EF English Proficiency Index) (2020). Retrieved from https://www.ef.com.tr/epi/ on 11.03.2021.

Gedikoğlu, T. (2005). Avrupa birliği sürecinde Türk eğitim sistemi: Sorunlar ve çözüm önerileri. Mersin Üniversitesi Ĕ̆itim Fakültesi Dergisi, 1(1), 66-80.

Halliwell, S. (1993). Teaching English in the primary classroom. London: Longman.

Harmer, J. (2007). The practice of English language teaching (4th ed.). London: Pearson Education Limited.

Haznedar, B. (2010). Türkiye'de yabancı dil eğitimi: Reformlar, yönelimler ve öğretmenlerimiz. Paper presented at the International Conference on New Trends in Education and Their Implications, 11-13 November, 2010, 747-755.

Işık, A. (2008). Yabancı dil eğitimimizdeki yanlışlar nereden kaynaklanıyor? Journal of Language and Linguistic Studies, 4(2), 15-26.

İnal, S., Evin, İ., \& Saracaloğlu, A. S. (2005). The relation between students' attitudes toward foreign language and foreign language achevement. Dil Dergisi, 130, 37-52.

Inceçay, G. (2012). Turkey's foreign language policy at primary level: Challenges in practice. ELT Research Journal, 1(1), 53-62.

İnci, S., \& Yıldız, S. (2019). Perceptions of English teachers in Turkey and Germany. Universal Journal of Educational Research, 7(2), 436-449.

Kara, E., Demir Ayaz, A., \& Dündar, T. (2017). Challenges in EFL speaking classes in Turkish context. European Journal of Language and Literature Studies, 3(2), 66-74.

Karc1, C., \& Akar-Vural, R. (2011). Teachers' views with regard to teaching English in multigraded classroom. Elementary Education Online, 10(2), 593-607.

Kırkgöz, Y. (2008). Curriculum innovation in Turkish primary Education. Asia-Pacific Journal of Teacher Education, 36(4), 309-322.

Kırkgöz, Y. (2014). Students' perceptions of English language versus Turkish language used as the medium of instruction in higher education in Turkey. Turkish Studies, 9(12), 443-459.

Kızıldağ, A. (2009). Teaching English in Turkey: Dialogues with teachers about the challenges in public primary schools. International Electronic Journal of Elementary Education, 1(3), 188-201.

Krashen, S. (1982). Principles and practice in second language learning and acquisition. Oxford: Pergamon.

MEB (Milli Eğitim Bakanlığı) (2018a). İngilizce dersi öğretim program (ilkokul ve ortaokul 2, $3, \quad 4, \quad 5, \quad 6, \quad 7$ ve $8 . \quad$ siniflar). $\quad$ Retrieved from http://mufredat.meb.gov.tr/ProgramDetay.aspx?PID=327 on 02.03.2020.

MEB (Milli Eğitim Bakanlığı) (2018b). Ortaöğretim İngilizce dersi (9, 10, 11 ve 12. sınıflar) öğretim programı. Retrieved from http://mufredat.meb.gov.tr/ProgramDetay.aspx?PID=342 on 02.03.2020.

Miles, M. B., \& Huberman, A. M. (1994). Qualitative data analysis: An expanded sourcebook (2nd ed.).Thousand Oaks, CA: Sage Publications.

Mirici, İ. H. (2001). Çocuklara yabancı dil öğretimi: İlköğretim 4. ve 5. sinıflar örneği. Ankara: Gazi Kitapevi.

Özer, B., \& Korkmaz, C. (2016). Yabancı dil öğretiminde öğrenci başarısını etkileyen unsurlar. EKEV Akademi Dergisi, 67, 59-84.

Öztosun, M. S. (2011). A qualitative study into English language teachers' and students' beliefs and practices in Turkey. The International Journal of Research in Teacher Education, 2(2), 16-34. 
Öztürk, G., \& Aydın, B. (2019). English language teacher education in Turkey: Why do we fail and what policy reforms are needed? Anadolu Journal of Educational Sciences International, 9(1), 181-213.

Paker, T. (2007). Çal bölgesindeki okullarda İngilizce öğretiminin sorunları ve çözüm önerileri. In B. Topuz, R. Urhan, \& M. A. Gülel (Eds.), 21. yüzyıla girerken geçmişten günümüze Çal yöresi, (pp. 684-690), Denizli: Toprak.

Patton, Q. M. (1990). Qualitative evaluation and research methods (2nd ed.). London, UK: Sage Publications.

Peker, B. G. (2012). Materyal değerlendirmede prensipler ve kriterler: Türkiye'de yabancı dil eğitiminde eğilim ne olmalı? Hacettepe üniversitesi eğitim fakültesi İngiliz dili eğitimi anabilim dalı 1. yabancı dil eğitimi çalıştayı bildirileri. Ankara: Hacettepe Üniversitesi Yayınları.

Saldana, J. (2009). The coding manual for qualitative researchers. Thousand Oaks, CA: Sage Publications.

Salı, P. (2014). An analysis of the teachers' use of L1 in Turkish EFL classrooms. System, 42, 308-318.

Seferoğlu, G. (2004). A study of alternative English teacher certification practices in Turkey. Journal of Education for Teaching, 30(2), 151-159.

Seferoğlu, G. (2006). Teacher candidates' reflection on some components of a pre-service English teacher education programme in Turkey. Journal of Education for Teaching, 32(4), 369-378.

Solak, E., \& Bayar, A. (2015). Current challenges in English language learning in Turkish EFL context. Participatory Educational Research, 2(1), 106-115.

TEPAV. (2013). Turkey national needs assessment of state school English language teaching. Ankara: Mattek Matbaacılık Basım Yayın Tanıtım.

TEPAV. (2015). Türkiye'de yükseköğretim kurumlarındaki İngilizce eğitimi: Bir durum analizi. Ankara: Yorum Basın Yayın Sanayi.

Toköz Göktepe, F. (2014). Speaking problems of 9th grade high school Turkish learners of L2 English and possible reasons for those problems: Exploring the teachers and students' perspectives. Procedia- Social and Behavioral Sciences, 116, 1875-1879.

Uysal, H. H. (2012). İngilizce eğitiminde denetim sorunları ve bir çözüm yolu olarak hizmetiçi eğitim ve bağlama duyarlı bireysel yönlendirme. Hacettepe üniversitesi eğitim fakültesi İngiliz dili eğitimi anabilim dalı 1. yabancı dil eğitimi çalıştayı bildirileri. Ankara: Hacettepe Üniversitesi Yayınları.

Ünal, M., \& İlhan, E. (2017). A case study on the problems and suggestions in foreign language teaching and learning at higher education. Journal of Education and Training Studies, 5(6), 64-72.

Yaman, İ. (2018). Türkiye'de İngilizce öğrenmek: Zorluklar ve firsatlar. RumeliDe Dil ve Edebiyat Araştırmaları Dergisi, 11, 161-175.

Yılmaz, C. (2008). Evaluating EFL coursebooks with respect to communicative language principles in the Turkish context. The 5th International ELT Research Conference. Onsekiz Mart Üniversitesi, Çanakkale, 23-25 May.

Yin, R. (1994). Case study research: Design and methods (2nd ed.). Thousand Oaks, CA: Sage Publications.

Yurtsever Bodur, G., \& Arıkan, A. (2017). Why can't we learn English?: Students' opinions at Akdeniz University. Gaziantep University Journal of Educational Sciences, 1(1), 1-7. 


\section{Appendix A. The structured form for problems and solutions}

Dear Participant,

The researcher kindly invites you to answer the following question. The researcher assures you that your responses will only be used for scientific purposes and no information about your identity will be disclosed. Also, your responses will not have any impact on your assessment scores in any of the courses you take.

- Please, explain the problems that you encountered throughout your foreign language education process (i.e. primary, elementary, high school and preparatory course training) and write down possible suggestions to handle/prevent those problems.

\section{Copyrights}

Copyright for this article is retained by the author(s), with first publication rights granted to the Journal.

This is an open-access article distributed under the terms and conditions of the Creative Commons Attribution license (CC BY-NC-ND) (http://creativecommons.org/licenses/by-nc-nd/4.0/). 